\title{
A Novel Dinucleating Ligand-Containing Hexabenzimidazoles and Its Dinuclear Zinc Complex Bridged by a Carboxylate Group for the Hydrolysis of 2-Hydroxypropyl-p-nitrophenyl phosphate
}

\author{
Mohamed M. Ibrahim
}

Received: 20 May 2009/Accepted: 29 June 2009/Published online: 15 July 2009

(C) The Author(s) 2009. This article is published with open access at Springerlink.com

\begin{abstract}
A dinuclear zinc(II) complex with the ligand bis\{tris[2-(1-methylbenzimidazole-2-yl)ethyl]-methylamine\} nitrilotriacetic acid sodium salt, L, was synthesized and characterized. Complex formation of $\mathrm{L}$ with $\mathrm{Zn}^{2+}$ in aqueous acetone was studied by $\mathrm{Zn}^{2+}$ titration using ${ }^{1} \mathrm{H}$ NMR and UV-vis spectroscopies. Analysis of the titration data indicates the formation of a dizinc complex. The $v_{\mathrm{as}}\left(\mathrm{COO}^{-}\right)$and $v_{\mathrm{s}}\left(\mathrm{COO}^{-}\right)$stretches were observed at 1572 and $1450 \mathrm{~cm}^{-1}$, respectively. The low separation of the stretches, $\Delta_{\exp }=115 \mathrm{~cm}^{-1}$, is an indication of chelating coordination of the carboxylate group between the two zinc(II) ions. The catalytic activity of $\left[\mathrm{LZn}_{2}\right]^{3+} \mathbf{1}$, as a model for phosphatase that catalyze chemical transformation of phosphate ester, in the hydrolysis of the RNA model, 2-hydroxypropyl $p$-nitrophenyl phosphate, was examined in aqueous acetone buffer solution, $\mathrm{pH}$ 7.0-9.5. The mechanism of the catalytic hydrolysis suggests that the rate of acceleration is due to what is called double Lewis acid activation.
\end{abstract}

Keywords Syntheses - Dinuclear zinc(II) complex · Metalloenzyme modelling $\cdot$ RNA $\cdot$ HPNP hydrolysis

Electronic supplementary material The online version of this article (doi:10.1007/s10904-009-9294-4) contains supplementary material, which is available to authorized users.

M. M. Ibrahim ( $\square)$

Chemistry Department, Faculty of Education,

Kafrelsheikh University, Kafrelsheikh 33516, Egypt

e-mail: ibrahim652001@yahoo.com

M. M. Ibrahim

Chemistry Deprtment, Faculty of Science, Taif University,

888 Alhawiya, Taif, Kingdom of Saudi Arabia

\section{Introduction}

In nature, chemical transformations of phosphate esters by metalloenzymes are generally facilitated by the cooperative action of two zinc(II) ions, e.g., P1 nuclease, DNA polymerase I, phospholipase $C$, and alkaline phosphatase [1-4]. It has been proposed [5-8] that, the dizinc centers are bridged by carboxylate groups of the amino acid sidechains and function as Lewis acids for the activation of the phosphate group, generate a reactive nucleophile, and stabilize both the penta-coordinate phosphorous transition state and the leaving group. Investigation into the use of multinuclear zinc(II) complexes containing bridged carboxylate as biomimetic compounds would be of a value to be synthesized as structural models and clarify the significance of two closely zinc centers in phosphate ester hydrolysis [9-22].

There have been many research efforts to design and synthesize mononuclear zinc(II) complexes for promoting the hydrolysis of 2-hydroxypropyl-p-nitrophenyl phosphate (HPNP) [23-26], and a simple strategy for the design of dinuclear catalysts is to connect two mononuclear zinc ligands by a short tether. Cooperative interaction between metal ions can be promoted by incorporation of functionality within the tether, which will allow it to serve as a scaffold for chelation of the two metal ions [27].

Recently, many synthetic mononuclear and dinuclear zinc(II) complexes [28-32] of ligands incorporating benzimidazoles have drawn much attention, because they are useful to elucidate the nature of the active site of the hydrolytic enzyme [28-35] and the catalytic mechanism.

As part of our studies in biomimetic hydrolytic zinc enzymes [28-30, 36-39] and with the aim to mimic the key features of the two zinc(II) centers in these metalloenzymes, we designed and synthesized a dizinc(II) complex 
$\left[\mathrm{LZn}_{2}\right]\left(\mathrm{ClO}_{4}\right)_{3} \mathbf{1}$ where $\mathrm{L}$ is a novel dinucleating ligand containing two tridentate tris $(N$-methylbenzimidazolylethyl)methane subunits bridged by carboxylate group (Scheme 1). Steric preorganization of the zinc(II) ions by the relatively rigid benzimidazole moieties facilitates the incorporation of substrate binding and catalysis. ${ }^{1} \mathrm{H}$ NMR, UV-Vis, and ESI-Mass studies in solution suggest that the solution structure of $\mathbf{1}$ is related to the dizinc core in hydrolytic enzymes. Kinetic studies on the hydrolysis of the activated RNA model 2-hydroxypropyl-p-nitrophenyl phosphate as a function of $\mathrm{pH}$ and the ratio of zinc(II) ions to ligand $\mathrm{L}$ are also presented here. Our interest was to understand functions of metal ions in biological hydrolysis process.

\section{Experimental Section}

\subsection{Materials}

All reagents and solvents were of analytical grade. Compounds tris[2-(1-methylbenzimidazole-2-yl)ethyl]nitromethane I and tris[2-(1-methylbenzimidazole-2-yl)-ethyl]methylamine II have been synthesized by the previously described method [40]. The barium(II) salt of the phosphate diester HPNP was synthesized by literature methods [41]. Nitrilotriacetic acid (NTA) and $\mathrm{N}$-methyl- $O$-phenylenediamine were purchased from Sigma. ${ }^{1} \mathrm{H}$ NMR spectra were measured by a JEOL EX-400 spectrometer. The kinetic studies were carried out using a Shimazdzu UV-visible 2450 spectrophotometer equipped with a Shimadzu TB-85 temperature controller.

Caution Perchlorate salts of amine ligands and their metal complexes are potentially explosive and should be used in small quantities.

\subsection{Syntheses}

\subsubsection{Synthesis of Bis\{tris[2-(1-methylbenzimidazole- 2-yl)ethyl]methylamine /nitrilotriacetic acid $L$}

A total of $0.394 \mathrm{~g}(0.78 \mathrm{mmol})$ of compound I in dry DMF $(5 \mathrm{~mL})$ was added to an ice cold solution of dicyclohexylcarbodiimide $(0.177 \mathrm{~g}, 0.86 \mathrm{mmol})$, 1-hydroxybenzotriazole $(0.149 \mathrm{~g}, 0.78 \mathrm{mmol})$ in dry DMF $(5 \mathrm{~mL})$. The $\mathrm{pH}$ was adjusted at to 7.0 by triethylamine. The reaction mixture was stirred at $0{ }^{\circ} \mathrm{C}$ for $2 \mathrm{~h}$ and at room temperature for $12 \mathrm{~h}$, filtered to remove dicyclohexylurea, and evaporated to give a solid. The obtained solid was suspended in dichloromethane $(30 \mathrm{~mL})$, extracted with $10 \mathrm{~mL}$ of sodium carbonate $(10 \%)$, dried, dissolved in ethyl acetate $(5 \mathrm{~mL})$ and aside at $4{ }^{\circ} \mathrm{C}$ overnight. Further dicyclohexylurea was filtered off and solvent was evaporated to give white precipitate. Anal. Calc. for $\mathrm{C}_{68} \mathrm{H}_{74} \mathrm{~N}_{15} \mathrm{O}_{4} \mathrm{Na} \cdot 10 \mathrm{H}_{2} \mathrm{O}: \mathrm{C}, 59.67$; H, 6.92; N, $15.36 \%$. Found: C, 60.10; H, 6.64; N, $14.73 \%$. ${ }^{1} \mathrm{H}$ NMR, $\delta_{\mathrm{H}}$ (DMSO- $d_{6}$ ) 7.47-7.43 and 7.31-7.25 and 7.24-7.05 (m, 24H benzimidazole $\mathrm{H}), 3.72\left(\mathrm{~s}, 4 \mathrm{H},-\mathrm{CH}_{2}-\right.$ $\mathrm{CONH}-$ ), $3.56\left(\mathrm{~s}, 18 \mathrm{H}, \mathrm{CH}_{3} \mathrm{~N}\right), 3.18$ (s, $2 \mathrm{H},-\mathrm{CH}_{2}-\mathrm{COO}-$ ), $2.92\left(\mathrm{t}, 12 \mathrm{H}\right.$, benzimidazole- $\left.\mathrm{CH}_{2}\right)$, and $2.46(\mathrm{t}, 12 \mathrm{H}$,
Scheme 1 The synthesis of ligand $\mathrm{L}$

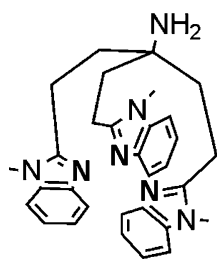

I

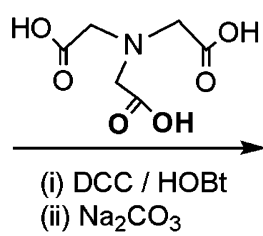

(ii) $\mathrm{Na}_{2} \mathrm{CO}_{3}$

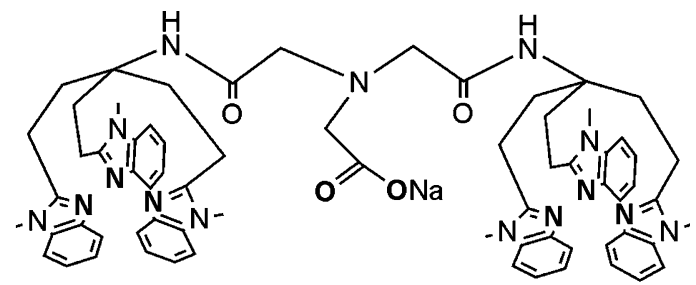

LNa

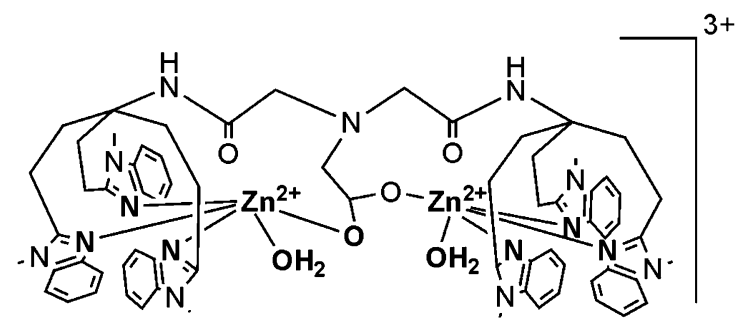

Zinc(II) complex 1<smiles>CC(O)COP(=O)([O-])Oc1ccc([N+](=O)[O-])cc1</smiles>

2-hydroxypropyl $p$ nitrophenyl phosphate
(HPNP) 
$\left.-\mathrm{CH}_{2} \mathrm{~N}\right) .{ }^{13} \mathrm{C} \quad \mathrm{NMP}, \quad \delta_{\mathrm{C}}\left(\mathrm{DMSO}-d_{6}\right) \quad 155.19,142.08$, $135.81,128.68,121.12,118.12$, and 109.57 (benzimidazole-C), $30.70\left(-\mathrm{CH}_{2}-\mathrm{N}\right), 29.44$ (benzimidazole- $\mathrm{CH}_{2}-$ ), $21.09\left(\mathrm{CH}_{3}-\mathrm{N}\right)$, and 173 (-COO-) ppm (-COO-). FT-IR $(\mathrm{KBr}): v\left(\mathrm{~cm}^{-1}\right): 1645$ and $1642 \mathrm{~cm}^{-1}$ [amide $\mathrm{I}(\mathrm{C}=\mathrm{O})$ ], 1570 and $1550 \mathrm{~cm}^{-1}$ [amide II $(\mathrm{C}=\mathrm{N})$ ], 1444 and 1473 [benzimidazole $(\mathrm{C}=\mathrm{N}-\mathrm{C}=\mathrm{C})], 1580 \mathrm{~cm}^{-1}\left[\mathrm{COO}^{-}\right]$. FABMass: $\mathrm{M}^{+} 1167$.

\subsubsection{Synthesis of $\left[\mathrm{LZn}_{2}\right]^{3+} \mathbf{1}$}

Complex 1 was prepared by the reaction between $\mathrm{L}$ $(0.068 \mathrm{~g}, 0.0497 \mathrm{mmol})$ and two equivalent amounts of $\mathrm{Zn}\left(\mathrm{ClO}_{4}\right)_{2} \cdot 6 \mathrm{H}_{2} \mathrm{O}(0.037 \mathrm{~g}, 0.099 \mathrm{mmol})$ in $\mathrm{EtOH}(80 \%$, $\mathrm{v} / \mathrm{v}$ ) on hot for $2 \mathrm{~h}$. White precipitated was formed on cooling. This complex was characterized by elemental analysis. Anal. Calc. for $\mathrm{C}_{68} \mathrm{H}_{74} \mathrm{~N}_{15} \mathrm{O}_{16} \mathrm{Cl}_{3} \mathrm{Zn}_{2} \cdot 12 \mathrm{H}_{2} \mathrm{O}: \mathrm{C}$, 46.41; H, 5.61; N, 11.94; Cl, 6.04\%. Found: C, 46.39; H, $4.95 ; \mathrm{N}, 11.94 ; \mathrm{Cl}, 5.12 \% .{ }^{1} \mathrm{H} \mathrm{NMP}, \delta_{\mathrm{H}}\left(\mathrm{DMSO}-d_{6}\right) 7.58-$ 7.51 and $7.40-7.32$ and $7.29-7.18(\mathrm{~m}, 24 \mathrm{H}$ benzimidazole $\mathrm{H}), 3.93$ (s, 4H, - $\mathrm{CH}_{2}-\mathrm{CONH}-$ ), 3.68 (s, 18H, $\left.\mathrm{CH}_{3} \mathrm{~N}\right), 3.28$ (s, 2H, $-\mathrm{CH}_{2}-\mathrm{COO}-$ ), $3.01\left(\mathrm{t}, 12 \mathrm{H}\right.$, benzimidazole- $\mathrm{CH}_{2}$ ), and $2.63\left(\mathrm{t}, 12 \mathrm{H},-\mathrm{CH}_{2} \mathrm{~N}\right)$. FT-IR $(\mathrm{KBr}): v\left(\mathrm{~cm}^{-1}\right): 1646$ and $1640 \mathrm{~cm}^{-1}$ [amide $\left.\mathrm{I}(\mathrm{C}=\mathrm{O})\right], 1571$ and $1549 \mathrm{~cm}^{-1}$ [amide II $(\mathrm{C}=\mathrm{N})$ ], 1453 and 1491 [benzimidazole $(\mathrm{C}=\mathrm{N}-$ $\mathrm{C}=\mathrm{C})], 1100 \mathrm{~cm}^{-1}\left[\mathrm{ClO}_{4}^{-}\right], 1457$ and $1572 \mathrm{~cm}^{-1}\left[\mathrm{COO}^{-}\right]$. Atomic absorption (observed, 9.25 and Calculated value, $10.09 \%$ ), which showed the ratio between $\mathrm{Zn}$ and $\mathrm{L}$ is $2: 1$. ESI-Mass for $\left[\mathrm{LZn}_{2}\right]^{3+}: \mathrm{M}^{+} 1294$.

\subsection{UV-Vis and ${ }^{1} \mathrm{H}$ NMR Measurements}

To confirm stoichiometry of zinc complex 1, UV-vis and ${ }^{1} \mathrm{H}$ NMR analysis of the nature of $\mathrm{L} / \mathrm{Zn}^{2+}$ binding were undertaken as a function of added $\mathrm{Zn}^{2+}$. The concentration of the ligand $\mathrm{L}\left(2 \times 10^{-4} \mathrm{M}\right)$ in aqueous acetone $(50 \%$ $\left(\mathrm{CH}_{3}\right)_{2} \mathrm{CO}$, v/v, $\left.I=0.1 \mathrm{M} \mathrm{NaNO}_{3}\right)$ was kept constant at $\mathrm{pH}$ around 8.5 at $25^{\circ} \mathrm{C}$. The changes in absorbance were recorded at $274 \mathrm{~nm}$. For NMR measurements, deuterated acetone and $\mathrm{D}_{2} \mathrm{O}$ in the ratio of $1: 1$ were used as a solvent mixture and the chemical shifts were reported relative to the resonance signal of sodium 2,2-dimethyl-2-silapentane5-sulfonate (DSS) as an internal standard. The pD was adjusted with concentrated $\mathrm{NaOD}$ and $\mathrm{DNO}_{3}$ solutions, so that the effect of dilution could be neglected.

\subsection{Experimental for Kinetic Measurements}

The cleavage of the barium(II) salt of HPNP, using zinc(II) complex 1 in aqueous acetone (50\% acetone, $\mathrm{v} / \mathrm{v}$, $I=0.1 \mathrm{M} \mathrm{NaNO}_{3}$ ) as a function of $\mathrm{pH}$ and zinc-to-ligand ratio, was followed by monitoring the increase in the visible absorbance at $394 \mathrm{~nm}$ caused by release of $p$-nitrophenolate [42]. The $\mathrm{pH}$ of solutions was adjusted by using Good's buffer in $0.05 \mathrm{M}$ concentration ( $\mathrm{pH} 7.0$ : MOPS; pH 7.5: HEPES; pH 8.0: EPPS; $\mathrm{pH} 8.5$ and 9.0: TAPS; and $\mathrm{pH}$ 9.5: CHES). Zinc complex of $0.5 \mathrm{mM}$ ligand was incubated at $25^{\circ} \mathrm{C}$, while the applied HPNP concentration was $20 \mu \mathrm{M}$. All reactions showed first-order characteristics. Reactions rates were corrected by blank experiments which were made up similarly but without the addition of zinc complex.

\section{Results and Discussion}

\subsection{Characterization of the Zinc(II) Model Complex 1}

The benzimidazole units attached to nitrilotriacetic acid (NTA) through amide bond model the histidine side chains of the active site of phosphohydrolase enzymes. The purpose of using zinc as a complexing ion was to keep the structural similarity between the native system and our model compounds. The synthesis of $\mathrm{L}$ was neatly performed in a one-pot process by the reaction between I and NTA using the conventional solution phase method by using the racemization free and fragment condensation strategies. Zinc complex 1 was prepared by the reaction of the ligand with two equimolar amounts of $\mathrm{Zn}\left(\mathrm{ClO}_{4}\right)_{2}$ in ethanol.

The IR spectrum of the free ligand has characteristic absorption bands at 1645 and $1642 \mathrm{~cm}^{-1}$ for amide I $(v \mathrm{C}=\mathrm{O}), 1570$ and $1550 \mathrm{~cm}^{-1}$ for amide II $(v \mathrm{C}=\mathrm{N}), 1444$ and 1473 for benzimidazole $(v \mathrm{C}=\mathrm{N}-\mathrm{C}=\mathrm{C})$, as well as the vibration of the carboxylate group at $1580 \mathrm{~cm}^{-1}$. The ${ }^{1} \mathrm{H}$ NMR of the ligand in DMSO- $d_{6}$ shows signals for both aliphatic and aromatic protons. A singlet arises at $12.26 \mathrm{ppm}$ due to the benzimidazole NH. A symmetric multiplet in the range of 7.47-7.05 ppm arises due to benzimidazole ring protons. Three singlets at 3.72, 3.56, and $3.18 \mathrm{ppm}$ arise due to the methylene protons of $-\mathrm{CH}_{2}-$ $\mathrm{CONH}-, \mathrm{N}-\mathrm{CH}_{3}$, and $-\mathrm{CH}_{2}-\mathrm{COO}^{-}$, respectively. Two triplets at 2.92 and 2.46 arise due to the methylene protons $\alpha$ and $\beta$, respectively. The FAB-Mass spectrum of the $\mathrm{LNa}$ in aqueous acetone $(50 \%)$ showed a molecular peak at $\mathrm{m} / \mathrm{z}$ 1167 (supporting information), corresponding to the anionic part of the ligand L. Upon complexation, an increase in the benzimidazole frequencies were observed, which is in accordance with the coordination of the ligand through the benzimidazolyl nitrogens [23-25]. The frequencies of the amides I and II have not been affected. In addition, the $v_{\text {as }}\left(\mathrm{COO}^{-}\right)$and $v_{\mathrm{s}}\left(\mathrm{COO}^{-}\right)$stretches were observed at 1572 and $1450 \mathrm{~cm}^{-1}$, respectively. The low separation of the stretches, $\Delta_{\exp }=115 \mathrm{~cm}^{-1}$, is an indication of chelating coordination of the carboxylate group [43]. 


\subsection{Chemical Species in Solution}

Herein we use ${ }^{1} \mathrm{H}$ NMR and UV-vis spectroscopes to study the structure of the obtained complexes postulated in this titration and, for cases when the potentiometric data are not available, to confirm that the two zinc(II) ions binds to the ligand under conditions similar to those in the kinetic experiments. The titration of the dinucleating ligand $\mathrm{L}$ with varying ratios of $\mathrm{Zn}^{2+}$ was studied in aqueous acetone $(50 \%, \mathrm{v} / \mathrm{v})$ at $\mathrm{pH} 9$ by using ${ }^{1} \mathrm{H}$ NMR spectroscopy as depicted in Fig. 1.

At $\mathrm{R}\left(\left[\mathrm{Zn}^{2+}\right]_{\mathrm{o}} /[\mathrm{L}]_{\mathrm{o}}\right)=0$, the ${ }^{1} \mathrm{H}$ NMR spectrum of the ligand shows that all peaks are well resolved, which were assigned as three multiplet signals of benzimidazole $(\mathrm{H} 4$, $\mathrm{H} 7$, and $\mathrm{H} 5,6)$, one singlet signal of $\left(-\mathrm{CO}-\mathrm{CH}_{2}-\mathrm{N}-\right)$, one singlet of (- $\left.\mathrm{CH}_{2}-\mathrm{COO}-\right)$, and two triplet signals of methylene $(\alpha$ and $\beta$ ) protons. Upon increasing $\mathrm{R}$ from 0 to 1.0 , an extensive broadening with downfield shift of all signals was observed, which is an evidence of a fast chemical exchange process between different species, most probably between the structural isomers of mononuclear zinc complex species and the free ligand. The effect of chemical exchange on the observed profiles gave coalescence between the free and complexed signals. The almost complete broadening of the benzimidazole protons as well as the methylene $\left(-\mathrm{CH}_{2}-\mathrm{COO}-\right)$ protons suggests that the donor ligation sites to zinc(II) ions are the benzimidazole nitrogens and the carboxylate oxygens, which are close to the broadened peaks. Upon increasing $\mathrm{R}$ to 2.0 , the

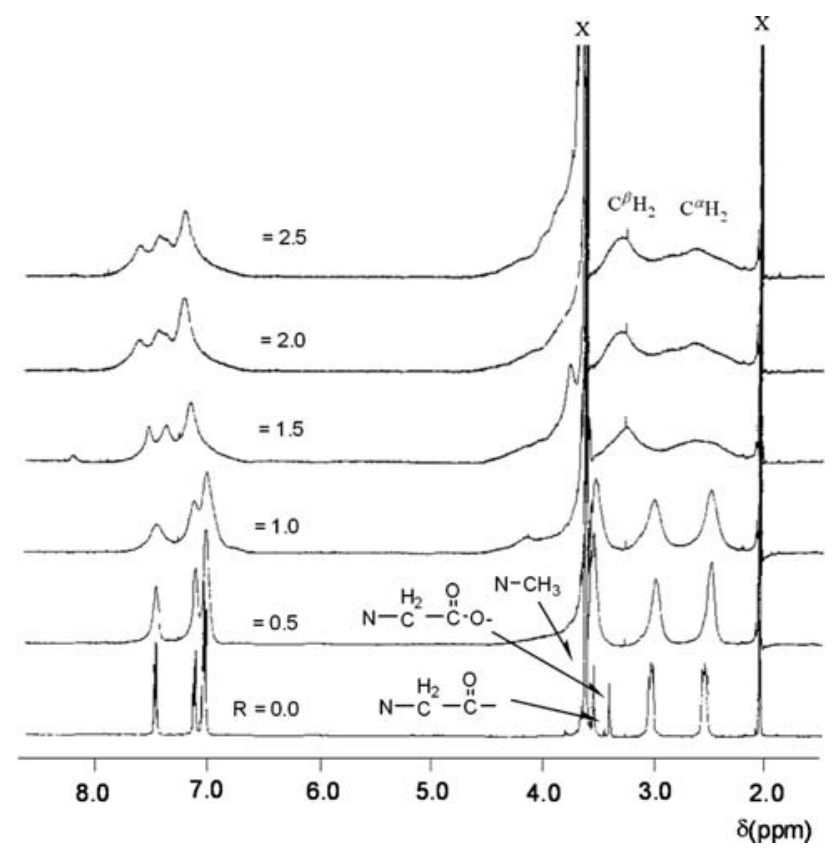

Fig. $1{ }^{1} \mathrm{H}$ NMR titration of $\mathrm{L}\left(2.0 \times 10^{-3} \mathrm{M}\right)$ as a function of $\mathrm{R}=\left[\mathrm{Zn}^{2+}\right]_{\mathrm{o}} /[\mathrm{L}]_{\mathrm{o}}=(0.0-3.0)$ in aqueous acetone $\mathrm{C}_{3} \mathrm{H}_{6} \mathrm{O}-d_{6}(50 \%$, $\mathrm{v} / \mathrm{v})$ at $\mathrm{pD} 8.5, I=0.1 \mathrm{M} \mathrm{NaNO}_{3}$ and $25{ }^{\circ} \mathrm{C}$ broadened peaks appear again, not completely sharp, especially the methylene protons close to the carboxylate groups. This indicates the formation of the new species dinuclear zinc complex with bridged carboxylate groups between the two zinc(II) ions, which are in accordance with the IR measurements in the solid state. Further addition of $\mathrm{Zn}^{2+}(\mathrm{R}>2.0)$ does not produce any change in the spectrum confirming that there is no further binding of $\mathrm{Zn}^{2+}$ ion. The kinetic liability of $\mathrm{Zn}_{2} \mathrm{~L}^{3+}$ demonstrates the higher flexibility of the molecule and a better organized coordination environment around zinc(II) ion. The peaks at $\mathrm{R}>2.0$ are not completely sharpened due to the rapid exchange processes of protons.

The formation of complex species was also determined spectrophotometrically by monitoring the increase in absorbance at $305 \mathrm{~nm}$ of the benzimidazolyl groups upon titration of the ligand with $\mathrm{Zn}\left(\mathrm{ClO}_{4}\right)_{2}$ in aqueous acetone (50\%) buffered at $\mathrm{pH} 9$. The absorption change of the ligand, as shown in Fig. 2, is saturated at $\mathrm{R}\left(\left[\mathrm{Zn}^{2+}\right]_{\mathrm{o}} /\right.$ $\left.[\mathrm{L}]_{\mathrm{o}}\right)=2.0$, indicating the formation of a 1:2 ligand:Zn(II) complex. When the ligand is titrated with excess of zinc(II) ions, an isobestic point appeared at $360 \mathrm{~nm}$ after one equivalent of zinc(II) ions with respect to ligand has been added. This indicates that the desired 1:2 complex is readily formed from 1:1 complex.

The formation of the dimeric complex $\left[\mathrm{LZn}_{2}\right]\left(\mathrm{ClO}_{4}\right)_{3}$ was also examined in solution. Complex 1 was dissolved in aqueous acetone $(50 \%)$ and the electrospray mass spectrum, as presented in Fig. 3, showed a major peak at $\mathrm{m} / \mathrm{z}$ 1229 (intensity 25\%), corresponding to the monomeric species $[\mathrm{LZn}]^{+}$and another mass peak is observed at $\mathrm{m} / \mathrm{z}$ 1294 (intensity 75\%), corresponding to the dimeric species $\left[\mathrm{LZn}_{2}\right]^{3+}$. The isotope pattern was in a good agreement with the theoretical one. The atomic absorption (AA)

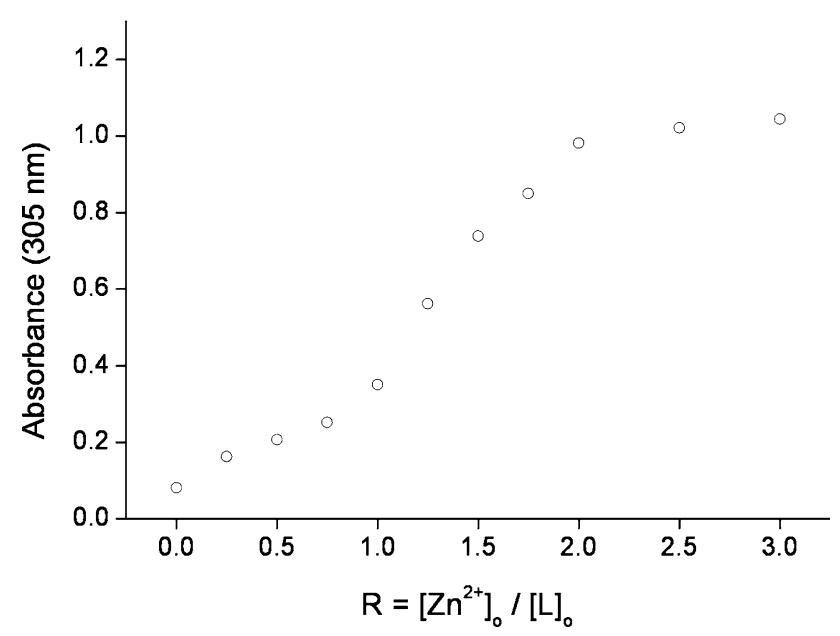

Fig. $2 \mathrm{UV}-$ vis titration of the ligand $\mathrm{L}\left(2.0 \times 10^{-4} \mathrm{M}\right) \mathrm{L}$ at different concentration of $\left[\mathrm{Zn}^{2+}\right]$ in aqueous acetone $(50 \%, \mathrm{v} / \mathrm{v})$ at $\mathrm{pH} 8.5$ (0.05 M EPPS, $I=0.1 \mathrm{M} \mathrm{NaNO}_{3}$ ), at $25{ }^{\circ} \mathrm{C}$ 
Fig. 3 a FAB-Mass spectrum of the ligand L; b ESI-Mass spectrum of the dinuclear zinc(II) complex $\mathbf{1}$ in aqueous acetone
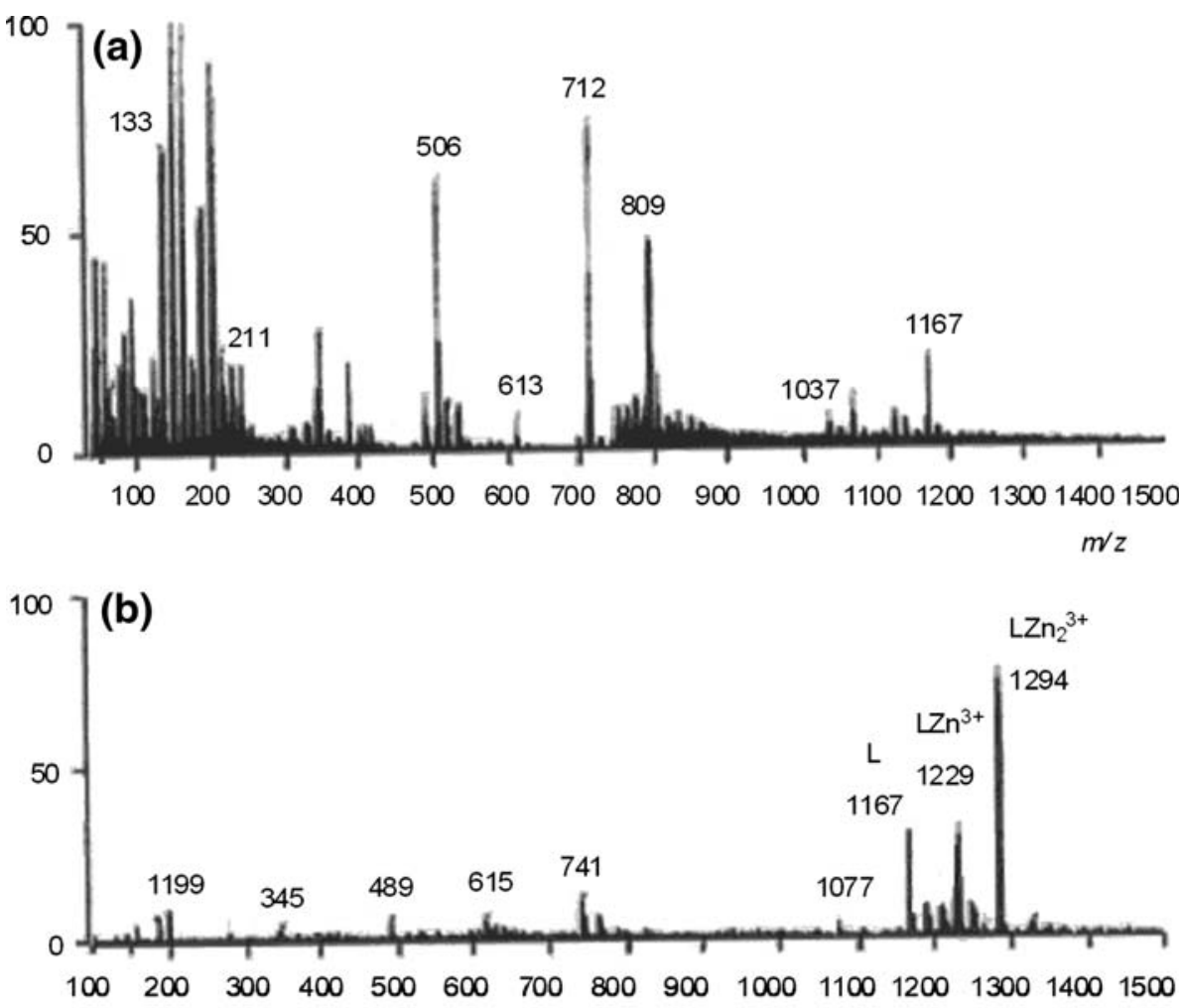

measurements of complex 1 in aqueous acetone (50\%) showed also that the ratio between $\mathrm{Zn}^{2+}$ and $\mathrm{L}$ is $2: 1$.

\section{$3.3 \mathrm{pH}$ and R-Dependent Kinetic Studies} on the Hydrolysis of HPNP

The catalytic activity of zinc(II) complex $\mathbf{1}$ with maximum stoichiometry is strongly influenced by the $\mathrm{pH}$ of the reaction mixture. The cleavage of the barium(II) salt of HPNP was followed by monitoring the increase in the visible absorbance at $394 \mathrm{~nm}$ caused by release of the $p$-nitrophenolate ion. The values of pseudo-first-order rate constants, $k_{\text {obs }}$ (Table 1) were obtained from the slopes of the plots of $\ln \left(\mathrm{A}-\mathrm{A}_{\infty}\right)$ vs. time (supplementary

Table 1 The observed pseudo-first order rate constants $\left(k_{\mathrm{obs}}, \mathrm{s}^{-1}\right)$ for the cleavage of HPNP $\left(8.0 \times 10^{-5} \mathrm{M}\right)$ by using zinc(II) complex 1 $\left(2.0 \times 10^{-3} \mathrm{M}\right)$ in aqueous acetone $(50 \%, \mathrm{v} / \mathrm{v})$ at different $\mathrm{pH}$ and $I=0.1 \mathrm{M} \mathrm{NaNO}_{3}$ and $25^{\circ} \mathrm{C}$

\begin{tabular}{ll}
\hline $\mathrm{pH}$ & $k_{\mathrm{obs}} / 10^{-6} \mathrm{~s}^{-1}$ \\
\hline 7.0 & 0.385 \\
7.5 & 0.622 \\
8.0 & 1.136 \\
8.5 & 2.292 \\
9.0 & 2.011 \\
9.5 & 1.869 \\
\hline
\end{tabular}

information) were linear, confirming the first order dependence on 1. Figure 4 shows a remarkable pH-rate profile via bell shaped curve between $\mathrm{pH} 7.0$ and 9.5 with a rate, $2.29 \times 10^{-6} \mathrm{~s}^{-1}$, optimum at $\mathrm{pH} 8.5$. This implies that the hydrolysis proceeds via an attack of zinc(II)-bound hydroxide ion. Below $\mathrm{pH} 8.5$, the rates of $\mathbf{1}$ promoted transesterification of HPNP increase with increase in the

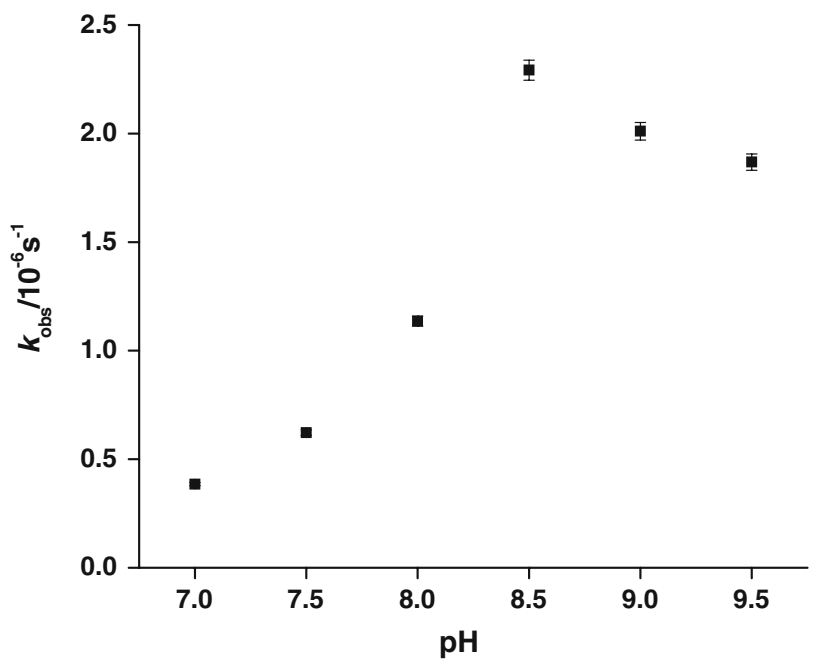

Fig. 4 Plot of $k_{\text {obs }}$ vs. pH. $[\mathrm{HPNP}]=8.0 \times 10^{-5} \mathrm{M}$, $[\mathbf{1}]=2.0 \times 10^{-3} \mathrm{M}$ in aqueous acetone $(50 \%, \mathrm{v} / \mathrm{v})$ at $I=0.1 \mathrm{M}$ $\mathrm{NaNO}_{3}$ and $25^{\circ} \mathrm{C}$ 
$\mathrm{pH}$. The rate levels off at $\mathrm{pH} 8.5$ indicating that the most active form of this dinuclear complex must have a hydroxide ion at one of its zinc(II) centers. The zinc(II)bound hydroxide ion can contribute to the hydrolysis by acting as a nucleophile [27-30].

The evidence of cooperativity of the two zinc(II) ions in complex 1 was obtained by kinetic studies. These kinetic studies, Table 2 and Fig. 5, were carried out by keeping constant the concentration of the ligand and adding increasing amounts of zinc(II) ions to a constant concentration of the ligand $\mathrm{L}$. The applied range of $\mathrm{R}\left(=\left[\mathrm{Zn}^{2+}\right]_{\mathrm{o}} /\right.$ $[\mathrm{L}]_{\mathrm{o}}$ ) for the ligand was decided on the basis of the preliminary results of R-dependent ${ }^{1} \mathrm{H}$ NMR and UV-vis titration results. As the concentration of the binding sites becomes larger than the concentration of zinc(II) ions available in solution, the rate acceleration decreases and eventually the rates becomes slower. It can be generally concluded that an increase in the degree of complexation has resulted in gradual acceleration in the hydrolysis process. The R-dependence of rate constants showed a lower

Table 2 The observed pseudo-first order rate constants $\left(k_{\mathrm{obs}}, \mathrm{s}^{-1}\right)$ for the cleavage of HPNP $\left(8.0 \times 10^{-5} \mathrm{M}\right)$ by at different $\mathrm{Zn}^{2+} / \mathrm{L}$ ratios in aqueous acetone $(50 \%, \mathrm{v} / \mathrm{v})$ at $\mathrm{pH} 8.5$, in $0.05 \mathrm{M}$ EPPS $(\mathrm{N}-2-$ hydroxyethyl)piperazine- $N^{\prime}$-3-propanesulfonic acid) buffer at $25{ }^{\circ} \mathrm{C}$

\begin{tabular}{ll}
\hline $\mathrm{R}=\mathrm{Zn}^{2+} / \mathrm{L}$ & $k_{\mathrm{obs}} / 10^{-6} \mathrm{~s}^{-1}$ \\
\hline 0.5 & 0.531 \\
1.0 & 0.857 \\
1.5 & 1.574 \\
2.0 & 2.358 \\
3.0 & 1.868 \\
\hline
\end{tabular}

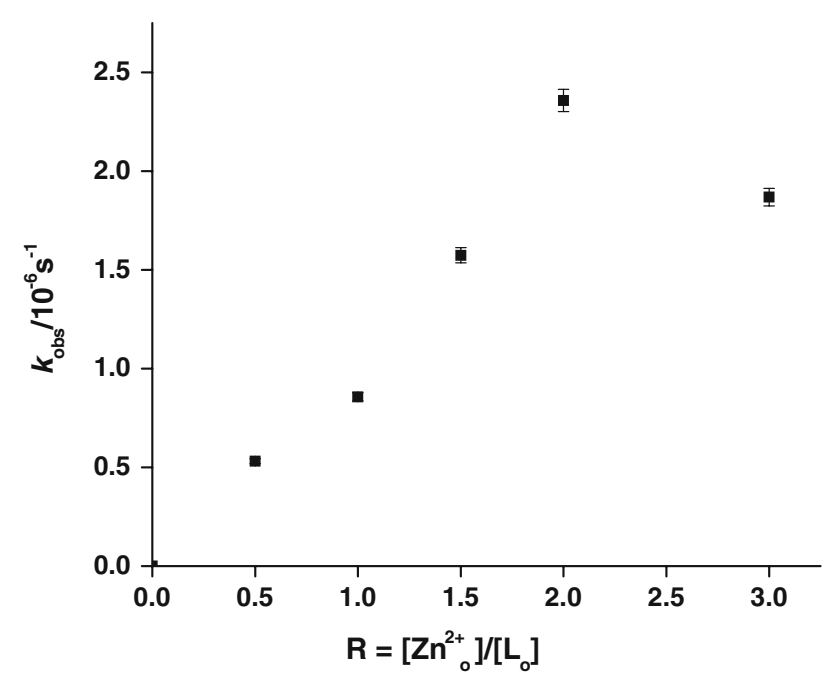

Fig. 5 Plot of $k_{\text {obs }}$ vs. $\mathrm{R}=\left[\mathrm{Zn}^{2+}\right]_{\mathrm{o}} /[\mathrm{L}]_{\mathrm{o}}$. [HPNP $]=8.0 \times 10^{-5} \mathrm{M}$ in aqueous acetone $(50 \%, \mathrm{v} / \mathrm{v})$ at $\mathrm{pH} 8.5(0.05 \mathrm{M}$ EPPS $), I=0.1 \mathrm{M}$ $\mathrm{NaNO}_{3}$ and $25{ }^{\circ} \mathrm{C}$ activity below $\mathrm{R}=1$. This can be explained by the higher coordination number of zinc, more precisely the larger variety of donor groups in the ligand. The highly coordinated central zinc in the mononuclear complex species might reduce the nucleophilicity of the bound-water molecule, and at the same time, may leave no sufficient free space around the coordinated water to interact with the phosphate ester substrate. The rate constants increase sharply between $1 / 1$ and 2/1 metal-to-ligand ratio (Table 2) indicating the high catalytic activity of the formed dinuclear complex species. Since the concentration of the complexed catalytic zinc centers becomes doubles in $2 / 1$ metal-to-ligand ratio in comparison with the equimolar case. The rate constants level off above $\mathrm{R}=2$, consisting with the NMR and UV titration results that showed $2 / 1$ as a maximum complex stoichiometry. A number of related dinuclear metal complexes have been studied by Trogler and coworkers [44]. They observed that the dinuclear complexes have a higher affinity to DNA binding than the corresponding mononuclear complexes. However, no notable rate enhancements were observed for the dinuclear compounds in the catalytic cleavage of activated phosphate esters.

Based on this, the bridging carboxylate group in $\left[\mathrm{LZn}_{2}\right]^{3+}$ may play a role in the mechanism of cleavage of HPNP similar to the bridging ligands in enzymes that utilize two metal ions. Dinuclear functional motifs in the active centers of metalloenzymes have the metal ions bridged by an endogenous anionic amino acid, usually Asp or Glu, or by an exogenous ligand such as water or hydroxide [2]. Consequently, the electrostatic repulsions between metal ions are reduced by the bridging carboxylate group and they can come in close proximity to function as a catalytic unit. The observed kinetic results, along with the ${ }^{1} \mathrm{H}$ NMR data, which shows no additional change in the ${ }^{1} \mathrm{H}$ NMR spectrum upon addition of a third equivalent of $\mathrm{Zn}$ (II) ion, suggests that the primary species present in solution under these conditions has also two zinc(II) ions.

All the above experimental results strongly suggest that in the dinuclear zinc(II) complex 1, zinc(II) sites act cooperatively in the hydrolysis of HPNP. A mechanism that is consistent with the $\mathrm{pH}$ dependence as well as the rate-ratio for complex $\mathbf{1}$ promoted transesterification of HPNP, as shown in Scheme 2. Such double Lewis-acid activation mechanism had been proposed for dinuclear metal complexes promoted cleavage of phosphate diester [45, 46].

\section{Conclusion}

A new ligand, namely bis\{tris[2-(1-methylbenzimidazole2-yl)ethyl]methylamine \}-nitrilotriacetic acid sodium salt, 


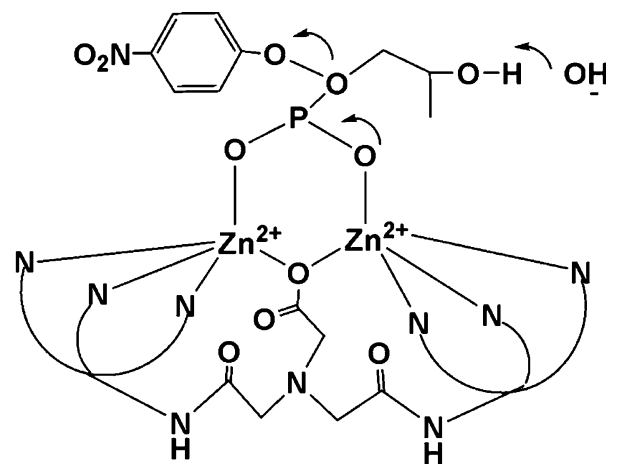

Scheme 2 The proposed mechanism for the hydrolysis of HPNP by using zinc(II) complex $\mathbf{1}$

L, has been synthesized and well characterized. Its dinuclear zinc(II) complexes has also been synthesized and characterized as structural model for the active site of phosphatase. Solution studies using ${ }^{1} \mathrm{H}$ NMR and UV-vis spectroscopies have been carried out to investigate the complex formation of $\mathrm{L}$ with $\mathrm{Zn}^{2+}$ in aqueous acetone. Analysis of the titration data indicates the formation of dizinc complex with bridged carboxylate group between the two zinc(II) ions. The mechanism of the catalytic hydrolysis of 2-hydroxypropyl-p-nitrophenyl phosphate using the dinuclear zinc(II) complex $\left[\mathrm{LZn}_{2}\right]^{3+} \mathbf{1}$ suggests that the rate of acceleration is due to what is called double Lewis acid activation.

Acknowledgment The author is grateful to Dr. Máté Tarnai, Anorganisch-Chemisches Institut, Universität Heidelberg, Im Neuenheimer Feld 270, D-69120 Heidelberg, Germany for his valuable discussions of this work.

Open Access This article is distributed under the terms of the Creative Commons Attribution Noncommercial License which permits any noncommercial use, distribution, and reproduction in any medium, provided the original author(s) and source are credited.

\section{References}

1. N. Strater, W.N. Lipscomb, T. Klablunde, B. Krebs, Angew. Chem. Int. Ed. Engl. 35, 2024 (1996)

2. D.E. Wilcox, Chem. Rev. 96, 2435 (1996)

3. W.N. Lipscomb, N. Strater, Chem. Rev. 96, 2357 (1996)

4. G.C. Dismukes, Chem. Rev. 96, 2909 (1996)

5. E.E. Kim, H. Wyckoff, J. Mol. Biol. 218, 4498 (1991)

6. K.D. Karlin, Science 261, 701 (1993), and references therein

7. A.L. Feig, S.J. Lippard, Chem. Rev. 94, 759 (1994)

8. E.Y. Tshuva, S.J. Lippard, Chem. Rev. 104, 987 (2004), and references therein

9. M. Yashiro, A. Ishikubo, M. Komiyama, J. Chem. Soc. Chem. Commun. 1793 (1995)

10. M.J. Young, J. Chin, J. Am. Chem. Soc. 117, 10577 (1995)
11. T. Tanase, J.W. Yun, S.J. Lippard, Inorg. Chem. 34, 4220 (1995)

12. H. Steinhagen, G. Helmchem, Angew. Chem. Int. Ed. Engl. 35, 2339 (1996)

13. J.S. Seo, N. Sung, R.C. Hynes, J. Chin, J. Inorg. Chem. 35, 742 (1996)

14. M. Yashiro, A. Ishikubo, M. Komiyama, J. Chem. Soc. Chem. Commun. 83 (1997)

15. C. Bazzicalupi, A. Bencini, A. Bianchi, V. Fusi, C. Giorgi, P. Paoletti, B. Valtancoli, D. Zanchi, Inorg. Chem. 36, 2784 (1997)

16. P. Molenveld, W.M.G. Stikvoort, H. Kooijman, A.L. Spek, J.F.J. Engbersen, D.M.J. Reinhoudt, J. Org. Chem. 64, 3896 (1999)

17. K. Yamada, Y. Takahashi, H. Yamamura, S. Araki, K. Saito, M. Kawai, Chem. Commun. 1315 (2000)

18. T. Gajda, R. Kramer, A. Jancso, Eur. Inorg. Chem. 1635 (2000)

19. C. He, S.J. Lippard, J. Am. Chem. Soc. 122, 184 (2000)

20. S. Kawahara, T. Uchimaru, Eur. J. Inorg. Chem. 2437 (2001)

21. S. Albedyhl, D. Schnieders, A. Jancso, T. Gadja, B. Krebs, Eur. J. Inorg. Chem. 1400 (2002)

22. K. Worm, F. Chu, K. Matsumoto, M.D. Best, V. Lynch, E.V. Anslyn, Chem. Eur. J. 9, 741 (2003)

23. O. Iranzo, A.Y. Kovaleveky, J.R. Morrow, J.P. Richard, J. Am. Chem. Soc. 125, 1988 (2003)

24. Q. Liu, H. Chen, H. Lin, H. Lin, J. Mol. Catal. A 269, 104 (2007)

25. I. Szilágyi, S. Mikkola, H. Lönnberg, I. Labádi, I. Pálinkó, J. Inorg. Biochem. 101, 1400 (2007)

26. M.-Y. Yang, J.R. Morrow, J.P. Richard, J. Biorg. Chem. 35, 366 (2007)

27. O. Iranzo, T. Elmer, J.P. Richard, J.R. Morrow, J.P. Richard, Inorg. Chem. 24, 7737 (2003)

28. K. Ichikawa, K. Nakata, M.M. Ibrahim, S. Kawabata, Stud. Surf. Sci. Catal. 114, 309 (1998)

29. K. Ichikawa, K. Nakata, M.M. Ibrahim, Chem. Lett. 796 (2000)

30. T. Echizen, M.M. Ibrahim, K. Nakata, M. Izumi, K. Ichikawa, M. Shiro, J. Inorg. Biochem. 98, 1347 (2004)

31. K.L. Klinkel, L.A. Kiemele, D.L. Gin, J.R. Hagadorn, J. Mol. Catal. A 267, 173 (2007)

32. S.C. Mohapatra, S. Tehlan, M.S. Hundal, P. Mathur, Inorg. Chim. Acta 361, 1897 (2008)

33. R. Breslow, D. Berger, D.L. Huang, J. Am. Chem. Soc. 112, 3686 (1990)

34. S. Uhlenbrock, B. Krebs, Angew. Chem. Int. Ed. Engl. 31, 1647 (1992)

35. J.R. Morrow, L.A. Buttrey, V.M. Skelton, K.A. Berback, J. Am. Chem. Soc. 114, 1903 (1992)

36. M.M. Ibrahim, N. Shimomura, K. Ichikawa, M. Shiro, Inorg. Chim. Acta 213, 125 (2001)

37. M.M. Ibrahim, K. Ichikawa, M. Shiro, Inorg. Chim. Acta 353, 187 (2003)

38. M.M. Ibrahim, K. Ichikawa, M. Shiro, Inorg. Chem. Commun. 6, 1030 (2003)

39. M.M. Ibrahim, Inorg. Chem. Commun. 9, 1215 (2006)

40. L. Casella, E. Monzani, M. Gullotti, F. Gliubich, L.D. Gioia, J. Chem. Soc., Dalton Trans. 3203 (1994)

41. D.M. Brown, D.A. Usher, J. Chem. Soc. 6558 (1965)

42. O. Iranzo, T. Elmer, J.P. Richard, J.R. Morrow, Inorg. Chem. 42 (2003)

43. V. Zeleňák Z. Vargov, K. Györyová, Spectrochim. Acta, Part A 66 (2007)

44. E.A. Kesicki, M.A. De Rosch, L.H. Freeman, C.L. Walton, D.F. Harvey, W.C. Trogler, Inorg. Chem. 32, 5851 (1993)

45. M. Wall, R.C. Hynes, J. Chin, Angew. Chem. Int. Ed. Engl. 32, 1633 (1993)

46. B. Takasaki, J. Chin, J. Am. Chem. Soc. 116, 1121 (1994) 